\title{
Keterpakaian dan relevansi Jurnal Agritech sebagai rujukan artikel jurnal ilmiah internasional terindeks Scopus
}

\author{
Sri Junandi \\ Perpustakaan Universitas Gadjah Mada \\ Jl. Bulaksumur, Kotak Pos 16, Yogyakarta, 55281 \\ E-mail: s_junandi@ugm.ac.id
}

Received: December 2017; Accepted: June 2018; Published: 2018

\begin{abstract}
Universitas Gadjah Mada through its Publishing Agency (BPP) aims to improve the quality of scientific journals, among others through internationalisation by including them to reputable indexing institutions. One of the requirements of internationalisation of scientific journals is that the articles in the journal have been cited by other articles in reputable international journals. Another requirement is the use of primary reference resources by the article comes from relevant and new scientific journals and proceedings. This study aimed to (1) identify the usage of Jurnal Agritech as the reference in published articles in international scientific journals indexed by Scopus, and (2) examine the refereed themes (Jurnal Agritech) in the article themes (other reputable journals). The study used the descriptive research method with quantitative approach. Data collection was conducted in February - March 2017 at Gadjah Mada University Library. Study results showed that Jurnal Agritech was used as a reference in articles published by international scientific journals indexed by Scopus. From the eight international scientific journals, the number of referred articles in Jurnal Agritech was one to six articles. Overall, articles published in the eight international scientific journals indexed by Scopus have referred to literatures relevant to Jurnal Agritech. It is therefore important that Jurnal Agritech is enhanced through the internationalization program by including it in the indexing agency.
\end{abstract}

Keywords: Jurnal Agritech; Scientific papers; Reference; Relevance; International journal

\begin{abstract}
Abstrak
Badan Penerbit dan Publikasi (BPP) Universitas Gadjah Mada (UGM) adalah badan yang mengelola publikasi yang berasal dari civitas akademika termasuk mengelola penerbitan jurnal. Salah satu jurnal yang telah terbit dan berkembang adalah Jurnal Agritech. BPP UGM terus berupaya meningkatkan kualitas jurnal ilmiah antara lain melalui internasionalisasi dengan indeksasi ke lembaga pengindeks bereputasi. Salah satu persyaratan internasionalisasi jurnal ilmiah adalah artikel yang diterbitkan sering dirujuk oleh artikel lain yang diterbitkan jurnal internasional bereputasi. Selain itu penggunaan sumber acuan primer oleh artikel tersebut berasal dari jurnal ilmiah dan prosiding yang relevan dan baru. Kajian ini bertujuan untuk mengetahui (1) keterpakaian Jurnal Agritech sebagai rujukan artikel dalam jurnal ilmiah internasional terindeks Scopus, dan (2) relevansi topik rujukan dengan topik artikel tersebut. Metode yang digunakan adalah penelitian deskriptif dengan pendekatan kuantitatif. Pengambilan data dilaksanakan pada bulan Februari - Maret 2017 di Perpustakaan Universitas Gadjah Mada. Hasil kajian menunjukkan bahwa Jurnal Agritech digunakan sebagai rujukan dalam artikel yang dipublikasikan oleh jurnal ilmiah internasional yang terindek Scopus. Hasil kajian ini juga menunjukkan bahwa dari delapan jurnal ilmiah internasional terindeks Scopus, jumlah rujukan pada Jurnal Agritech berkisar 1-6 rujukan. Secara keseluruhan, artikel yang diterbitkan pada delapan jurnal ilmiah internasional terindeks Scopus sudah merujuk literatur yang relevan dengan topik Jurnal Agritech. Ini menunjukkan bahwa manajemen dan kualitas Jurnal Agritech perlu ditingkatkan dengan program internasionalisasi yaitu dengan mengikuitsertakan dalam index ke Scopus.
\end{abstract}

Kata kunci: Jurnal Agritech; Karya tulis ilmiah; Rujukan; Relevansi; Jurnal internasional 


\section{PENDAHULUAN}

Salah satu keberhasilan perguruan tinggi ditentukan oleh kualitas dan kuantitas hasil penelitian yang telah memberi manfaat secara nyata dan optimal kepada pengguna baik peneliti, akademisi maupun masyarakat pada umumnya baik nasional dan internasional. Universitas Gadjah Mada sebagai lembaga perguruan tinggi telah berkontribusi dalam pembangunan pertanian nasional dengan menghasilkan berbagai teknologi yang sebagian telah dimanfaatkan pengguna yaitu peneliti, penyuluh pertanian, pengusaha agribisnis, pengajar, mahasiswa, pelajar, penentu kebijakan, dan petani.

Salah satu media komunikasi untuk menyebarluaskan hasil penelitian adalah jurnal. Jurnal adalah bentuk terbitan yang berfungsi meregistrasi kegiatan kecendekiaan, mensertifikasi hasil kegiatan yang memenuhi persyaratan ilmiah minimum, mendiseminasikannya secara meluas kepada khalayak ramai, dan mengarsipkan semua temuan hasil kegiatan kecendekiaan ilmuwan dan pandit yang dimuatnya. Jurnal terdiri empat tingkatan, yaitu jurnal nasional, jurnal terakreditasi, jurnal internasional, dan jurnal internasional bereputasi (Kemendikbud, 2014). Bagi dosen, jurnal ilmiah bukan hanya sekedar sarana untuk sosialisasi hasil penelitian, tetapi juga menentukan profesionalisme karena dosen dituntut membuat karya tulis ilmiah (KTI) sebagai salah satu persyaratan bagi jabatan fungsional dosen. Apabila seorang dosen berhasil mempublikasikan karya ilmiahnya pada jurnal internasional bereputasi akan mendapat pengakuan atau bobot yang maksimal dibandingkan pada jurnal tingkat bawahnya. Staf pengajar/dosen yang tidak produktif mempublikasikan KTI akan mengalami hambatan dalam karir jabatan fungsionalnya. Hal ini sesuai pendapat Sumarno (2010) dalam Hermanto and Sunihardi (2010) yang mengungkapkan bahwa peneliti, terutama yang bernaung di bawah lembaga penelitian pemerintah, dituntut menulis dan mempublikasikan hasil penelitian yang telah dilakukan sebagai bentuk pertanggungjawaban atas penggunaan dana dan fasilitas penelitian agar masyarakat mengetahui dan memanfaatkan hasil penelitian tersebut. Hal serupa dikemukakan oleh Sutardji (2012), bahwa KTI hasil penelitian yang dipublikasikan berperan penting dalam promosi jabatan fungsional dan pengembangan karir.

Media publikasi KTI antara lain adalah jurnal ilmiah hasil penelitian, baik dalam bentuk cetak maupun elektronik. Akreditasi bagi jurnal ilmiah telah diberlakukan di Indonesia, sejak tahun 2015 dengan diterbitkannya Peraturan Kepala LIPI nomor 1 tahun 2014 dan Peraturan Direktur Jenderal Pendidikan Tinggi Nomor 1 tahun 2014 tentang Pedoman Akreditasi Terbitan Berkala Ilmiah, maka pengajuan akreditasi secara elektronik melalui aplikasi Akreditasi Jurnal Nasional (Arjuna).

Apabila jurnal ilmiah sudah berhasil terakreditasi sebaiknya ditindaklanjuti dengan indeksasi ke lembaga pengindeks. Menurut Widodo (2017), terdapat tiga tingkatan reputasi lembaga pengindeks yaitu tinggi, sedang dan rendah. Lembaga pengindeks bereputasi tinggi memiliki beberapa kriteria antara lain bidang ilmu yang diindeks beragam, mempunyai basis data yang sangat besar, mempunyai perangkat untuk analisis sitasi dan pemeringkat jurnal, 
menjadi acuan dalam pemeringkatan perguruan tinggi tingkat dunia, dan relatif sangat selektif untuk terindeks, misalnya Scopus (Elsevier) dan Web of Science. Lembaga pengindeks bereputasi sedang memiliki kriteria antara lain dapat meliputi dan menjadi acuan indeksasi di bidang ilmu tertentu, mempunyai database yang cukup besar, tidak perlu memiliki perangkat analisis sitasi dan pemeringkat jurnal, relatif selektif untuk bisa terindeks, misalnya Directory of Open Acces Journal (DOAJ), EBSCO, PubMed, Gale, ProQuest, Chemical Abstract Services (CAS), CABI, Compendex, Engineering Village, Inspec, dan/atau pengindeks lainnya yang setara. Sedangkan lembaga pengindeks bereputasi rendah memiliki kriteria antara lain dapat menjadi acuan indeksasi di bidang ilmu tertentu, mempunyai database yang cukup besar, tidak perlu memiliki perangkat analisis sitasi dan pemeringkatan jurnal, serta relatif tidak selektif untuk dapat terindeks, misalnya Google Scholar, Portal Garuda, ISJD, Moraref, Mendeley, CiteULike, WorldCat, Sherpha/Romeo dan/atau pengindeks lainnya yang setara.

Indeksasi adalah pendaftaran

jurnal pada lembaga pengindeks. Indeksasi bertujuan untuk mendiseminasikan metadata artikel terbitan berkala ilmiah sehingga lebih mudah ditemukan dengan cara mencatatkan metadata tersebut di lembaga pengindeks. Lembaga pengindeks selanjutnya akan mempromosikan kepada publik. Jurnal ilmiah yang berhasil terindeks di beberapa database, maka secara tidak langsung akan memudahkan sitasi secara global. Semakin meningkat jumlah sitasi jurnal, maka reputasi jurnal tersebut akan meningkat. Lembaga pengindeks yang bereputasi selalu menerapkan seleksi yang ketat saat menerima pendaftaran terbitan berkala ilmiah supaya terindeks. Beberapa pengindeks menerapkan mekanisme pemeringkatan terbitan berkala ilmiah dalam bentuk perbandingan jumlah sitasi/acuan terhadap jumlah artikel yang dipublikasi dalam kurun waktu tertentu, misalnya Impact Factor (IF), Scimago Journal Ranking (SJR), nilai h-index atau lainnya yang sejenis.

Salah satu aspek penting yang dinilai dalam proses akreditasi jurnal ilmiah adalah daftar pustaka dari KTI dalam jurnal tersebut. Daftar pustaka yang disarankan yang memiliki derajat kemutakhiran 10 tahun terakhir dan komposisi $>80 \%$ berasal dari jurnal ilmiah atau prosiding. Daftar pustaka merupakan kumpulan dari literatur yang dirujuk penulis dalam menyusun KTInya. Junandi (2015) mengungkapkan bahwa relevansi antara subjek judul publikasi pustakawan dengan judul artikel yang disitir yang sebagian besar dimanfaatkan dalam pendekatan teori dan diskusi hasil kajian. Rujukan yang dipakai dalam KTI harus relevan dengan aspek yang diteliti dan dibahas. Dalam hal ini diperlukan kemampuan literasi informasi, sesuai dengan topik yang dibahas. Menurut Septiyantono (2014), literasi informasi sebagai kemampuan seseorang mengenali kapan informasi itu dibutuhkan serta seperangkat ketrampilan yang dimiliki dalam mencari, menemukan, menganalisis, mengevaluasi dan mengkomunikasikan informasi yang berfungsi dalam pemenuhan kebutuhan informasi bertujuan memecahkan berbagai masalah. Sementara itu, Suwanto (2015) mengatakan bahwa literasi informasi 
adalah seperangkat keterampilan untuk mengenali kapan informasi dibutuhkan, baik itu untuk kepentingan akademisi ataupun pribadi, termasuk lingkup tempat kerja; melalui proses pencarian, penemuan dan pemanfaatan informasi dari beragam sumber; serta mengkomunikasikan pengetahuan baru ini dengan efektif dan efisien. Berdasarkan uraian tersebut dapat dikatakan bahwa literasi informasi adalah kemampuan dalam menemukan informasi yang dibutuhkan, mengerti bagaimana perpustakaan diorganisasi, bisa menggunakan sumber daya informasi yang tersedia (termasuk format kemasan informasi dan alat penelusuran yang terautomasi), serta cara yang digunakan dalam pencarian informasi.

Akreditasi terhadap jurnal ilmiah di Indonesia telah dilakukan Dikti dalam upaya peningkatan kualitas jurnal ilmiah nasional yang diterbitkan oleh perguruan tinggi. Pada tahun 2014, Direktorat Jenderal Pendidikan Tinggi telah menerbitkan Pedoman Akreditasi Terbitan Berkala Ilmiah. Salah satu persyaratan akreditasi jurnal ilmiah adalah kualitas dan kuantitas sumber acuan primer yang digunakan. Jurnal ilmiah dinilai baik kalau nisbah sumber acuan primer sama atau lebih $80 \%$ berasal dari terbitan terbaru proporsi 10 tahun terakhir (kecuali bidang-bidang tertentu yang tidak banyak pembaharuan seperti hukum, taksonomi, dan arkeologi). Menurut Hermanto (2013a), hal ini berhubungan erat dengan tingkat kedalaman dan aktualitas materi pembahasan, perkembangan penelitian yang menjadi subjek tulisan, dan kualitas KTI itu sendiri.

Jurnal Agritech adalah jurnal ilmiah hasil penelitian yang diterbitkan oleh
Fakultas Teknologi Pertanian Universitas Gadjah Mada. Jurnal ini terbit empat kali dalam setahun sebagai media komunikasi ilmiah bagi peneliti untuk mengkomunikasikan hasil-hasil penelitian bidang teknologi pertanian kalangan peneliti, dosen dan ilmuwan lainnya. Hal ini sesuai dengan Bachtiar (2016) yang mengatakan bahwa fungsi jurnal ilmiah merupakan salah satu sarana komunikasi ilmiah yang populer di kalangan para ilmuwan berbagai ilmu. Jurnal merupakan media komunikasi formal antara sesama ilmuwan. Jurnal Agritech tidak hanya diperuntukkan bagi dosen di lingkungan Universitas Gadjah Mada, tetapi juga peneliti atau staf pengajar di lembaga penelitian lain dan perguruan tinggi. Saat ini perguruan tinggi telah memberlakukan syarat wajib bagi mahasiswa program magister dan doktor untuk menerbitkan KTI hasil penelitian pada jurnal ilmiah terakreditasi. Dalam kaitan ini, Jurnal Agritech banyak mendapat kiriman KTI dari mahasiswa S2 dan S3 selain staf pengajar di lingkungan Universitas Gadjah Mada dan perguruan tinggi lainnya.

Jurnal Agritech terakreditasi untuk pertama kalinya pada tahun 1998 dengan nomor 111/DIKTI/Kep/1998. Pada tahun 2001 terakreditasi kembali dengan nomor 134/DIKTI/Kep/2001, tahun 2005 tetap terakreditasi dengan nomor 26/DIKTI/Kep/2005, tahun 2009 berhasil mempertahankan akreditasi dengan nomor 83/DIKTI/Kep/2009, tahun 2012 dengan momor No. 56/DIKTI/Kep/2012, dan tahun 2017 dengan nomor 32a/E/KPT/2017 berlaku untuk lima tahun ke depan sampai dengan 26 April 2022 (Kemenristekdikti, 2017). Jurnal Agritech sudah berhasil mempertahankan 
status akreditasi dari tahun 1998 sampai sekarang. Selain itu juga artikel Jurnal Agritech sering dirujuk oleh penulis artikel pada jurnal ilmiah internasional yang terindeks Scopus, sehingga sudah memenuhi salah satu persyaratan untuk meraih jurnal internasional bereputasi yaitu terindeks lembaga pengindeks bereputasi tinggi misalnya Scopus.

Kemanfaatan jurnal ilmiah dalam pembangunan nasional antara lain bergantung pada keterpakaiannya dalam pengembangan ilmu pengetahuan dan teknologi. Peneliti sering kali tidak menyadari KTI yang dirujuk oleh penulis lain sebagai salah satu referensi bagi KTI yang dipublikasikan pada jurnal ilmiah, sebagaimana terlihat pada daftar pustaka. Kajian ini bertujuan untuk mengetahui (1) keterpakaian Jurnal Agritech sebagai rujukan KTI yang terbit dalam jurnal ilmiah internasional yang terindeks Scopus, (2) relevansi topik artikel rujukan dengan topik KTI yang dipublikasikan.

\section{METODE PENELITIAN}

Dalam penelitian ini metode yang digunakan adalah metode deskriptif dengan pendekatan kuantitatif. Penelitian ini ingin mengetahui data dalam angka keterpakaian dan relevansi artikel Jurnal Agritech dalam KTI jurnal internasional terindeks Scopus. Menurut Arikunto (2010), metode penelitian deskriptif adalah penelitian yang dimaksudkan untuk mengumpulkan informasi mengenai status suatu gejala yang ada, yaitu keadaan gejala menurut apa adanya pada saat penelitian dilakukan. Dengan kata lain penelitian deskriptif hanya menggambarkan apa adanya tentang suatu variabel, gejala atau keadaan, tidak untuk menguji hipotesis tertentu. Maka data hasil yang diperoleh dari keterpakaian dan relevansi dari artikel Jurnal Agritech yang menjadi rujukan dalam artikel jurnal internasional terindeks Scopus dideskripsikan sesuai data dan kondisi yang berlangsung sampai saat ini.

Subjek dalam penelitian ini yaitu delapan jurnal ilmiah internasional terindeks Scopus, sedangkan objek adalah judul artikel karya tulis ilmiah dari delapan jurnal ilmiah internasional terindeks Scopus yang merujuk artikel Jurnal Agritech.

Pelaksanaan kajian ini dilakukan pada bulan Februari-Maret 2017 di Perpustakaan Universitas Gadjah Mada. Kajian dilakukan terhadap delapan jurnal internasional yang terindeks Scopus. Jurnal-jurnal ilmiah tersebut diambil secara selektif berdasarkan topik KTI di dalamnya atau yang memuat KTI hasil penelitian bidang teknologi pertanian. Kedelapan jurnal ilmiah yang dikaji telah terindeks Scopus. Nama jurnal, nomor dan tahun akreditasi, tahun terbit, dan penerbit disajikan pada Tabel 1.

Data yang diperoleh dengan cara "Citation Analysis" yang disediakan pada website Jurnal Agritech menunjukkan sebanyak 66 artikel Jurnal Agritech dirujuk pada artikel jurnal internasional terindeks Scopus, sejak diterbitkan mulai tahun 1980 Volume 1 sampai Volume 37 tahun 2017 diupdate 2 Maret 2017. Data tersebut diolah dengam lembar kerja dalam bentuk 4 tabel menggunakan Microsoft excel, tabel 1 terdiri 3 kolom meliputi (1) nomor urut, (2) nama jurnal \& terbitan (volume, no. tahun), (3) nama penerbit, tabel 2 terdiri 5 kolom meliputi (1) nomor urut, (2) nama jurnal \& terbitan (volume, no. tahun) (3) judul karya tulis ilmiah, (4) jumlah rujukan, (5) jumlah rujukan dari Jurnal Agritech, tabel 3 terdiri 4 kolom 
meliputi (1) nomor urut, (2) tahun \& terbitan (volume, no, halaman) (3) judul karya tulis ilmiah yang disitat, (4) terbit pada jurnal, dan tabel 4 terdiri 4 kolom meliputi (1) nomor urut, (2) nama jurnal, (3) judul karya tulis ilmiah, (4) judul karya tulis ilmiah rujukan dari Jurnal Agritech.

Parameter yang dikaji adalah (1) keterpakaian artikel Jurnal Agritech sebagai rujukan dalam KTI jurnal internasional terindeks Scopus dan (2) relevansi topik KTI dari jurnal internasional terindeks Scopus dengan topik artikel rujukan dari Jurnal Agritech. Data yang diperoleh dianalisis secara deskriptif untuk mendapat gambaran keterpakaian Jurnal Agritech sebagai rujukan KTI yang terbit dalam jurnal internasional yang terindeks Scopus, dan relevansi rujukan dengan topik KTI yang dipublikasikan.

\section{HASIL DAN PEMBAHASAN}

Hasil kajian menunjukkan bahwa Jurnal Agritech telah dirujuk oleh sebagian staf pengajar/dosen dan peneliti dalam KTI-nya yang diterbitkan pada jurnal internasional yang terindeks Scopus. Jumlah literatur yang dirujuk dalam KTI yang dikaji berkisar antara 4-58 literatur dengan jumlah rujukan dari Jurnal Agritech antara 1-6 rujukan per tulisan (Tabel 2). Sebagai bukti keterpakaian satu KTI yang terbit pada International Food Research Journal menggunakan artikel Jurnal Agritech sebagai rujukan, pada International Journal on Advanced Science, Engineering and Information Technology, dua KTI yang diterbitkan menggunakan artikel Jurnal Agritech sebagai rujukan sebanyak dua KTI. Sebanyak enam rujukan pada Journal of Environmental Hydrology dari satu KTI. Selanjutnya pada
International Journal of Poultry Science, Journal of Applied Sciences, Jurnal Teknologi, Media Peternakan, penggunaan artikel Jurnal Agritech sebagai rujukan KTI relatif intens, yaitu sebanyak enam belas rujukan dari empat KTI, sedangkan pada Pakistan Journal of Nutrition ada sebanyak delapan rujukan dari dua KTI. Hal ini dapat dilihat dari daftar pustaka KTI yang diterbitkan pada kedelapan jurnal tersebut.

Berdasarkan uraian tersebut di atas menunjukkan benar-benar bahwa artikel Jurnal Agritech sudah dimanfaatkan sebagai rujukan dalam KTI jurnal ilmiah internasional terindeks Scopus merupakan bukti keterpakaian Jurnal Agritech sampai saat ini.

Salah satu bukti pemanfaatan hasil penelitian oleh peneliti lain dapat dilihat dari KTI yang dirujuk dalam penyusunan proposal dan laporan hasil penelitian maupun sebagai rujukan dari KTI yang diterbitkan pada jurnal ilmiah internasional. Bukti ini dapat dilihat dari daftar pustaka KTI tersebut. Daftar pustaka merupakan kumpulan dari literatur yang dirujuk peneliti dalam menyusun KTI. Daftar pustaka berfungsi untuk memberikan penghargaan kepada penulis terhadap hasil karyanya dengan topik yang sama atau hampir sama. Selain itu juga memberikan arah bagi peneliti lain yang berminat melakukan kajian atau penelitian dengan topik atau subjek yang sama.

Pada Tabel 3 menunjukkan bahwa judul artikel hasil penelitian pada Jurnal Agritech yang menjadi rujukan peneliti dalam tulisan ilmiahnya. Terdapat 15 artikel dari Jurnal Agritech yang dirujuk oleh penulis dalam KTI yang diterbitkan pada delapan jurnal internasional terindeks Scopus yang dikaji. Satu KTI 
yang terbit pada Internasional Food Research Journal menggunakan artikel dalam Jurnal Agritech sebagai bahan rujukan, dua KTI terbit pada International Journal on Advanced Science, Engineering and Information Technology. Selanjutnya pada Journal of Environmental Hydrology, pemakaian Jurnal Agritech sebagai rujukan KTI sebanyak enam rujukan dari dua KTI peneliti. Pada International Journal of Poultry Science, Journal of Applied Sciences, Jurnal Teknologi, dan Media Peternakan, pemakaian Jurnal Agritech sebagai bahan rujukan KTI sebanyak enam belas rujukan dari delapan artikel. Sedangkan pada Pakistan Journal of Nutrition pemakaian Jurnal Agritech sebagai rujukan sebanyak delapan rujukan dari empat artikel.

Berdasarkan uraian tersebut di atas menunjukkan juga bahwa pemakaian Jurnal Agritech sebagai rujukan dalam KTI jurnal internasional terindeks Scopus semakin meningkat sampai saat ini. Kumpulan literatur pada daftar pustaka menjadi perhatian utama peneliti untuk dijadikan inspirasi bagi pengembangan latar belakang dan pembahasan hasil penelitian. Hal ini sesuai dengan Pebriyanti (2015) bahwa data, simpulan, dan informasi lain yang terkandung dalam karya ilmiah dapat dijadikan acuan bagi penulis dalam melaksanakan penelitian atau pengkajian selanjutnya.

Hasil kajian menunjukkan bahwa rujukan dari Jurnal Agritech yang dipakai penulis sudah relevan dengan topik KTI yang dipublikasikan (Tabel 4). Sebagai bukti relevansi topik KTI yang dipublikasikan pada International Food Research Journal dengan judul "Aggregation and adhesion abilities to enterocyte-like HCT-116 cells of probiotic candidates Lactobacillus plantarum strains isolated from "mandai", Indonesian fermented food against enteropathogens merujuk artikel di Jurnal Agritech berjudul "Characterization of lactic acid bacteria isolates from mandai function as probiotic" berbasis fermentasi mandai, sama dengan topik KTI yang dirujuk.

Pada International Journal of Poultry Science, dua judul KTI Jurnal Agritech yang dirujuk adalah "Lactic Acid Bacteria in Fermented Foods of Indonesian Origin" dan "Isolasi dan Seleksi Lactobacillus yang Berpotensi sebagai Agensia Probiotik". Rujukan ini sebagai bukti relevan dengan topik KTI yang merujuk, yaitu "Characteristic of Lactobacillus Isolated from Pengging Duck's Intestines as Probiotics" dengan topik sama yaitu bakteri asam laktat.

Pada International Journal on Advanced Science, Engineering and Information Technology, peneliti menggunakan rujukan yang relevan dengan topik KTI-nya. Dua artikel KTI yang berjudul Applications of liquid smoke powder as flavor and food preservative (Case Study: Sponge Cake), dan Optimization Process for Production of Smoke Powder penulis menggunakan rujukan yang relevan dari artikel Jurnal Agritech berjudul Optimization Process for Production of Smoke Powder dengan topik tepung asap.

Selanjutnya pada Journal of Applied Sciences juga terlihat relevansi topik antara KTI yang dipublikasikan dengan rujukan yang dipakai. KTI dengan judul Characterization of Redistilled Liquid Smoke of Oil-Palm Shells and Its Application as Fish Preservatives memakai rujukan dua artikel dari Jurnal Agritech berjudul "Proses Pemurnian Asap Cair dan Simulasi Akumulasi Kadar Benzopyrene pada Proses Perendaman Ikan" dan "Optimasi Proses 
Pembuatan Tepung Asap" dengan topik tepung asap.

Sementara itu dalam Journal of Environmental Hydrology satu KTI berjudul "Model of soil water contents for various soil textures" merujuk dua artikel dari Jurnal Agritech yang relevan juga dengan judul "Effect of Soil Physical Properties on Saturated Hydraulic Conductivity in The 5 Land Use (A Case Study in Sumbersari Malang)" dan "Land Suitability Assessment of Corn (Zea may L) Using Spasial Analysis Methode" yang membahas topik sifat fisik tanah.

Selanjutnya pada Jurnal Teknologi satu KTI berjudul "Cassava starch-based edible coatings enriched with alpina purpurata and kaempferia rotunda essential oils for patin fillets preservation" peneliti merujuk dua artikel yang relevan dari Jurnal Agritech dengan judul "Antimicrobial activity of red ginger (Zingiber officinale var. Rubrum) and red galangal (Alpinia purpurata K. Schum) essential oils against pathogenicand food spoilage bacteria" dan "Effect of Edible Coating Enriched with Red Ginger and Red Galangal Essential Oil on the Quality of Patin Fillet" dengan topik minyak esensial dan antimikroba.

Pada Media Peternakan satu KTI berjudul "Utilization of durian seed flour as filler ingredient of meatball" peneliti merujuk dua artikel yang relevan juga dari Jurnal Agritech dengan judul "Karakteristik sifat fisikokimia pati garut (Maranta arundinaceae)" dan "Water absorption as reference to determine the volume of water in dough making from wheat flour and cassava flour mixture" dengan topik sifat fisikokimia pati garut.

Sementara itu pada Pakistan Journal of Nutrition terdapat dua artikel yang merujuk sebanyak empat artikel yang relevan dari Jurnal Agritech yaitu pertama berjudul "Resistant Starch Content and Glycaemic Index of Sago (Metroxylon Spp.) Starch and Red Bean (Phaseolus Vulgaris) Based Analogue Rice" merujuk dua artikel yang relevan berjudul "Indeks Glikemik Umbi-umbian" dan "Resistant Starch: Pembentukan, Metabolisme dan Aspek Gizinya" dengan topik indeks glikemik. Sedangkan artikel kedua berjudul "Changes in Resistant Starch Content and Glycemic Index of Pre-Gelatinized Gayam (Lnocarfus Fagifer Forst.) Flour" merujuk dua artikel yang relevan berjudul "Glycemic Index of Tuber Foods" dan "Resistant Starch: Pembentukan, Metabolisme dan Aspek Gizinya" yang membahas topik tentang indeks glikemik. Bukti-bukti tersebut di atas menunjukkan relevansi antara topik artikel rujukan dari Jurnal Agritech dengan topik KTI jurnal internasional terindeks Scopus. Berdasarkan hasil pembahasan tersebut di atas menunjukkan bahwa artikel yang dipublikasikan oleh Jurnal Agritech telah merujuk literatur yang relevan. Hal ini sesuai dengan persyaratan akreditasi bahwa KTI yang diterbitkan pada jurnal ilmiah terakreditasi harus merujuk sumber acuan primer yang relevan (LIPI, 2011). Relevansi topik KTI dengan rujukan yang dipakai penulis tidak terlepas dari peranan dewan redaksi jurnal ilmiah dalam menelisik setiap rujukan. Bagi Dewan Redaksi Jurnal Agritech, bagian pertama yang dilihat dari KTI hasil penelitian yang dikirimkan ke redaksi adalah daftar pustakanya, sebelum dibahas dalam rapat redaksi.

Terkait dengan pengukuran relevansi literatur yang dirujuk dengan topik KTI yang dipublikasikan pada jurnal ilmiah, penulis dituntut untuk mampu menguasai literasi informasi hasil penelitian sesuai dengan topik dan 
masalah yang ada. Hal ini sejalan dengan pendapat Hermanto (2013b) bahwa literasi informasi berperan penting dalam menyaring dan memilah informasi yang diperlukan.

\section{SIMPULAN}

Sesuai dengan tujuan penelitian keterpakaian Jurnal Agritech sebagai rujukan artikel dalam jurnal iilmiah internasional terindeks Scopus dan relevansi topik artikel rujukan dengan topik artikel Jurnal Agritech. Jurnal Agritech telah digunakan oleh para penulis sebagai rujukan dalam KTI yang dipublikasikan pada jurnal ilmiah internasional terindeks Scopus. Jumlah rujukan dari delapan jurnal ilmiah internasional terindeks Scopus ke KTI Jurnal Agritech berkisar 1-6 rujukan. Secara keseluruhan, KTI yang diterbitkan pada delapan jurnal ilmiah internasional terindeks Scopus sudah merujuk literatur yang relevan dengan topik KTI Jurnal Agritech. Jurnal Agritech adalah salah satu sumber rujukan relevan yang digunakan dalam KTI pada jurnal ilmiah internasional terindeks Scopus, sehingga disarankan bagi pengelola sudah saatnya untuk mengindekan ke Scopus untuk menuju jurnal ilmiah bereputasi internasional.

\section{DAFTAR PUSTAKA}

Arikunto, S. (2010). Manajemen penelitian. Jakarta: Rineka Cipta.

Bachtiar, A. C. (2016). Membangun media komunikasi ilmiah dalam perpustakaan perguruan tinggi. Pustakaloka: Jurnal Kajian Informasi Dan Perpustakaan, 8(2), 173-184. Retrieved from http://jurnal.stainponorogo.ac.id/in dex.php/pustakaloka/article/view/
$422 / 530$

Hermanto. (2013a). Akreditasi jurnal ilmiah semakin ketat: peneliti kurang tanggap? Bogor: Berita Puslitbangtan.

Hermanto. (2013b). Implementasi literasi informasi hasil penelitian kedelai dalam penulisan artikel ilmiah populer. Jurnal Perpustakaan Pertanian, 22(2), 59-68.

Hermanto \& Sunihardi. (2010). Peningkatan kinerja peneliti dan mutu publikasi ilmiah pada unit kerja penelitian. In Prosiding rapat kerja 2010: reformasi birokrasi dan diseminasi hasil penelitian tanaman pangan (pp. 51-66). Bogor: Puslitbang Tanaman Pangan.

Junandi, S. (2015). Analisis sitiran karya ilmiah pustakawan Indonesia pada

Jurnal Visi Pustaka tahun 2008-2013. Jurnal Berkala Ilmu Perpustakaan Dan Informasi, 11(1), 44-53. https://doi.org/https://doi.org/10. 22146/bip. 8840

Kemendikbud. (2014). Pedoman operasional penilaian angka kredit kenaikan pangkat/jabatan akademik dosen. Jakarta: Direktorat Jenderal Pendidikan Tinggi.

Kemenristekdikti. (2017). Surat Keputusan Direktur Jenderal Penguatan Riset dan Pengembangan, Kementrian Riset, Teknologi dan Pendidikan Tinggi Nomor 32a/E/KPT/2017 tentang hasil akreditasi terbitan berkala ilmiah elektronik periode 1 tahun 2017. Indonesia: Direktorat Jenderal Penguatan Riset dan Pengembangan, Kementrian Riset, Teknologi dan Pendidikan Tinggi.

LIPI. (2011). Pedoman akreditasi majalah ilmiah. Bogor: Pusat Pembinaan, Pendidikan, dan Pelatihan Peneliti 
LIPI.

Pebriyanti, Y. (2015). Kemas ulang informasi: kumpulan karya tulis ilmiah peneliti di lingkup Balai Penelitian dan Pengembangan Air Tawar (BPPAT) Bogor. Jurnal Pari, 1(1), 27-33.

Septiyantono, T. (2014). Materi pokok literasi informasi. Tangerang Selatan: Universitas Terbuka.

Sutardji. (2012). Produktivitas publikasi peneliti Balai Penelitian Tanaman
Kacang-kacangan dan Umbi-umbian. Jurnal Perpustakaan Pertanian, 21(1), 23-29.

Suwanto, S. A. (2015). Analisis literasi informasi pemakai TBM. Jurnal Kajian Informasi \& Perpustakaan, 3(1), 89-100. Retrieved from http://jurnal.unpad.ac.id/jkip/articl e/view/9492/4709

Widodo, et al. (2017). Panduan indeksasi, manajemen referensi, dan akreditasi jurnal. Yogyakarta: Gadjah Mada University Press. 


\section{DAFTAR TABEL}

Tabel 1

Jurnal ilmiah internasional terindeks Scopus dipilih secara selektif sebagai subjek kajian

\begin{tabular}{|c|c|c|}
\hline No. & $\begin{array}{l}\text { Nama } \\
\text { Jurnal }\end{array}$ & Penerbit \\
\hline 1 & $\begin{array}{l}\text { International Food Research Journal } \\
\text { Terindeks 2008-2017 } \\
23 \text { (5) } 2016\end{array}$ & Universiti Putra Malaysia \\
\hline 2 & $\begin{array}{l}\text { International Journal of Poultry Science } \\
\text { Terindeks 2002-2017 } \\
13 \text { (1) } 2014\end{array}$ & Asian Network for Scientific Information \\
\hline 3 & $\begin{array}{l}\text { International Journal on Advanced Science, } \\
\text { Engineering and Information Technology } \\
\text { Terindeks 2015-2017 } \\
5 \text { (2) } 2015\end{array}$ & $\begin{array}{l}\text { INSIGHT - Indonesian Society for Knowledge } \\
\text { and Human Development }\end{array}$ \\
\hline 4 & $\begin{array}{l}\text { Journal of Applied Sciences } \\
\text { Terindeks 2006-2013, } 2015 \\
13 \text { (3) } 2013\end{array}$ & Asian Network for Scientific Information \\
\hline 5 & $\begin{array}{l}\text { Journal of Environmental Hydrology } \\
\text { Terindeks } 1996 \text { - 2002, } 2005 \text { to } 2016 \\
232015\end{array}$ & $\begin{array}{l}\text { International Association for Environmental } \\
\text { Hydrology }\end{array}$ \\
\hline 6 & $\begin{array}{l}\text { Jurnal Teknologi } \\
\text { Terindeks 2010-2017 } \\
78 \text { (4-2) } 2016\end{array}$ & Universiti Teknologi Malaysia \\
\hline 7 & $\begin{array}{l}\text { Media Peternakan } \\
\text { Terindeks 2010-2016 } \\
39 \text { (3) } 2016\end{array}$ & Bogor Agricultural University \\
\hline 8 & $\begin{array}{l}\text { Pakistan Journal of Nutrition } \\
\text { Terindeks 2002, 2005-2017 } \\
15 \text { (7) } 2016\end{array}$ & Asian Network for Scientific Information \\
\hline
\end{tabular}

Sumber: Hasil penelitian, 2017 
Tabel 2

Keterpakaian Jurnal Agritech sebagai rujukan karya tulis ilmiah (KTI) pada jurnal internasional terindeks Scopus

\begin{tabular}{|c|c|c|c|c|}
\hline No. & Jurnal & Judul & $\begin{array}{l}\text { Rujukan } \\
\text { KTI }\end{array}$ & $\begin{array}{l}\text { Rujukan } \\
\text { dari } \\
\text { Agritech }\end{array}$ \\
\hline 1 & $\begin{array}{l}\text { International Food Research } \\
\text { Journal }\end{array}$ & $\begin{array}{l}\text { Aggregation and adhesion abilities to } \\
\text { enterocyte-like HCT-116 cells of probiotic } \\
\text { candidates Lactobacillus plantarum strains } \\
\text { isolated from "mandai", Indonesian } \\
\text { fermented food against enteropathogens }\end{array}$ & 22 & 1 \\
\hline 2 & $\begin{array}{l}\text { International Journal of } \\
\text { Poultry Science } \\
13 \text { (1) } 2014\end{array}$ & $\begin{array}{l}\text { Characteristic of Lactobacillus Isolated from } \\
\text { Pengging Duck's Intestines as Probiotics }\end{array}$ & 26 & 4 \\
\hline 3 & $\begin{array}{l}\text { International Journal on } \\
\text { Advanced Science, } \\
\text { Engineering and } \\
\text { Information Technology } \\
5 \text { (2) } 2015\end{array}$ & $\begin{array}{l}\text { Applications of liquid smoke powder as } \\
\text { flavor and food preservative (Case Study: } \\
\text { Sponge Cake) }\end{array}$ & 4 & 1 \\
\hline & 5 (6) 2015 & $\begin{array}{l}\text { The effect of adding liquid smoke powder to } \\
\text { shelf life of sauce }\end{array}$ & 5 & 1 \\
\hline 4 & 13 (3) 2013 & $\begin{array}{l}\text { Characterization of Redistilled Liquid Smoke } \\
\text { of Oil-Palm Shells and Its Application as } \\
\text { Fish Preservatives. }\end{array}$ & 40 & 4 \\
\hline 5 & $\begin{array}{l}\text { Journal of Environmental } \\
\text { Hydrology } \\
232015\end{array}$ & $\begin{array}{l}\text { Model of soil water contents for various soil } \\
\text { textures }\end{array}$ & 39 & 6 \\
\hline 6 & $\begin{array}{l}\text { Jurnal Teknologi } \\
78(4-2) 2016\end{array}$ & $\begin{array}{l}\text { Cassava starch-based edible coatings } \\
\text { enriched with alpina purpurata and } \\
\text { kaempferia rotunda essential oils for patin } \\
\text { fillets preservation }\end{array}$ & 58 & 4 \\
\hline 7 & $\begin{array}{l}\text { Media Peternakan } \\
39 \text { (3) } 2016\end{array}$ & $\begin{array}{l}\text { Utilization of durian seed flour as filler } \\
\text { ingredient of meatball }\end{array}$ & 52 & 4 \\
\hline 8 & $\begin{array}{l}\text { Pakistan Journal of } \\
\text { Nutrition }\end{array}$ & $\begin{array}{l}\text { Resistant Starch Content and Glycaemic } \\
\text { Index of Sago (Metroxylon Spp.) Starch and } \\
\text { Red Bean (Phaseolus Vulgaris) Based } \\
\text { Analogue Rice }\end{array}$ & 49 & 4 \\
\hline & 15 (7) 2016 & $\begin{array}{l}\text { Changes in Resistant Starch Content and } \\
\text { Glycemic Index of Pre-Gelatinized Gayam } \\
\text { (Lnocarfus Fagifer Forst.) Flour }\end{array}$ & 56 & 4 \\
\hline
\end{tabular}

Sumber: Hasil penelitian, 2017. 
Tabel 3

Artikel dari Jurnal Agritech yang dirujuk dalam karya tulis pada jurnal ilmiah internasional terindeks Scopus

\begin{tabular}{|c|c|c|c|}
\hline No. & Tahun & Karya tulis ilmiah yang dirujuk & Terbit pada Jurnal \\
\hline 1 & $\begin{array}{l}2015 \\
35 \text { (2): 146-155 }\end{array}$ & $\begin{array}{l}\text { Characterization of lactic acid bacteria isolates from } \\
\text { mandai function as probiotic }\end{array}$ & $\begin{array}{l}\text { International Food } \\
\text { Research Journal }\end{array}$ \\
\hline 2 & $\begin{array}{l}2003 \\
23(2): 67-74\end{array}$ & $\begin{array}{l}\text { Isolasi dan Seleksi Lactobacillus yang } \\
\text { Berpotensi sebagai Agensia Probiotik }\end{array}$ & $\begin{array}{l}\text { International Journal of } \\
\text { Poultry Science }\end{array}$ \\
\hline 3 & $\begin{array}{l}2003 \\
23(2): 75-84\end{array}$ & $\begin{array}{l}\text { Lactic Acid Bacteria in Fermented Foods of } \\
\text { Indonesian Origin }\end{array}$ & \\
\hline 4 & $\begin{array}{l}2002 \\
22(4): 172-177\end{array}$ & $\begin{array}{l}\text { Optimization Process for Production of Smoke } \\
\text { Powder }\end{array}$ & $\begin{array}{l}\text { International Journal } \\
\text { on Advanced Science. } \\
\text { Engineering and } \\
\text { Information Technology }\end{array}$ \\
\hline 5 & $\begin{array}{l}2006 \\
26(2): 74-83\end{array}$ & $\begin{array}{l}\text { Proses Pemurnian Asap Cair dan Simulasi } \\
\text { Akumulasi Kadar Benzopyrene pada Proses } \\
\text { Perendaman Ikan }\end{array}$ & $\begin{array}{l}\text { Journal of Applied } \\
\text { Sciences }\end{array}$ \\
\hline 6 & $\begin{array}{l}2002 \\
22(4): 172-177\end{array}$ & Optimasi Proses Pembuatan Tepung Asap & \\
\hline 7 & $\begin{array}{l}2011 \\
31(1): 71-78\end{array}$ & $\begin{array}{l}\text { Evaluasi Kesesuaian Lahan untuk Tanaman } \\
\text { Jagung Menggunakan Metode Analisis } \\
\text { Spasial. }\end{array}$ & $\begin{array}{l}\text { Journal of } \\
\text { Environmental } \\
\text { Hydrology }\end{array}$ \\
\hline 8 & $\begin{array}{l}2013 \\
33(3): 340-345\end{array}$ & $\begin{array}{l}\text { Effect of Soil Physical Properties on Saturated } \\
\text { Hydraulic Conductivity in The } 5 \text { Land Use (A Case } \\
\text { Study in Sumbersari Malang). }\end{array}$ & \\
\hline 9 & $\begin{array}{l}2013 \\
33(4): 399-406\end{array}$ & $\begin{array}{l}\text { Effect of Edible Coating Enriched with Red Ginger } \\
\text { and Red Galangal Essential Oil on the Quality of } \\
\text { Patin Fillet. }\end{array}$ & Jurnal Teknologi \\
\hline 10 & $\begin{array}{l}2015 \\
35(1): 43-52\end{array}$ & $\begin{array}{l}\text { Antimicrobial activity of red ginger (Zingiber } \\
\text { officinale var. Rubrum) and red galangal (Alpinia } \\
\text { purpurata K. Schum) essential oils against } \\
\text { pathogenicand food spoilage bacteria. }\end{array}$ & \\
\hline 11 & $\begin{array}{l}2014 \\
34(1): 14-21\end{array}$ & $\begin{array}{l}\text { Karakteristik sifat fisikokimia pati garut (Maranta } \\
\text { arundinaceae) }\end{array}$ & Media Peternakan \\
\hline 12 & $\begin{array}{l}2015 \\
35(3): 324-330\end{array}$ & $\begin{array}{l}\text { Water absorption as reference to determine the } \\
\text { volume of water in dough making from wheat flour } \\
\text { and cassava flour mixture }\end{array}$ & \\
\hline 13 & $\begin{array}{l}1998 \\
18(4): 29-35\end{array}$ & $\begin{array}{l}\text { Resistant Starch: Pembentukan, Metabolisme } \\
\text { dan Aspek Gizinya. }\end{array}$ & $\begin{array}{l}\text { Pakistan Journal of } \\
\text { Nutrition }\end{array}$ \\
\hline 14 & $\begin{array}{l}2002 \\
22(1): 13-16\end{array}$ & Glycemic Index of Tuber Foods & \\
\hline 15 & $\begin{array}{l}2002 \\
22(1): 13-16\end{array}$ & Indeks Glikemik Umbi-umbian & \\
\hline
\end{tabular}

Sumber: Hasil penelitian, 2017 
Tabel 4

Relevansi topik KTI yang terbit pada delapan jurnal internasional terindeks Scopus dengan KTI rujukan dari Jurnal Agritech

\begin{tabular}{|c|c|c|}
\hline No. & Jurnal & Karya tulis ilmiah \\
\hline 1 & $\begin{array}{l}\text { International } \\
\text { Food Research } \\
\text { Journal }\end{array}$ & $\begin{array}{l}\text { Aggregation and adhesion abilities to } \\
\text { enterocyte-like HCT-116 cells of probiotic } \\
\text { candidates Lactobacillus plantarum strains } \\
\text { isolated from "mandai", Indonesian fermented } \\
\text { food against enteropathogens }\end{array}$ \\
\hline 2 & $\begin{array}{l}\text { International } \\
\text { Journal of } \\
\text { Poultry } \\
\text { Science }\end{array}$ & $\begin{array}{l}\text { Characteristic of Lactobacillus Isolated from } \\
\text { Pengging Duck's Intestines as Probiotics }\end{array}$ \\
\hline \multirow[t]{2}{*}{3} & $\begin{array}{l}\text { International } \\
\text { Journal on } \\
\text { Advanced } \\
\text { Science, } \\
\text { Engineering } \\
\text { and }\end{array}$ & $\begin{array}{l}\text { Applications of liquid smoke powder as flavor } \\
\text { and food preservative (Case Study: Sponge } \\
\text { Cake) }\end{array}$ \\
\hline & $\begin{array}{l}\text { Information } \\
\text { Technology }\end{array}$ & $\begin{array}{l}\text { The effect of adding liquid smoke powder to } \\
\text { shelf life of sauce }\end{array}$ \\
\hline 4 & $\begin{array}{l}\text { Journal of } \\
\text { Applied } \\
\text { Sciences }\end{array}$ & $\begin{array}{l}\text { Characterization Of Redistilled Liquid Smoke } \\
\text { of Oil-Palm Shells and Its Application as Fish } \\
\text { Preservatives. }\end{array}$ \\
\hline
\end{tabular}

Judul KTI rujukan dari Jurnal Agritech

Characterization of lactic acid bacteria isolates

from mandai function as probiotic

Lactic Acid Bacteria in Fermented Foods of Indonesian Origin

Isolasi dan Seleksi Lactobacillus yang Berpotensi sebagai Agensia Probiotik Optimization Process for Production of Smoke Powder

Proses Pemurnian Asap Cair dan Simulasi Akumulasi Kadar Benzopyrene pada Proses Perendaman Ikan

Optimasi Proses Pembuatan Tepung Asap Effect of Soil Physical Properties on Saturated Hydraulic Conductivity in The 5 Land Use (A Case Study in Sumbersari Malang).

Land Suitability Assessment of Corn (Zea may L) Using Spasial Analysis Methode.

Antimicrobial activity of red ginger (Zingiber officinale var. Rubrum) and red galangal (Alpinia purpurata K. Schum) essential oils against pathogenicand food spoilage bacteria.

Effect of Edible Coating Enriched with Red Ginger and Red Galangal Essential Oil on the Quality of Patin Fillet.

Karakteristik sifat fisikokimia pati garut (Maranta arundinaceae)

Water absorption as reference to determine the volume of water in dough making from wheat flour and cassava flour mixture

Glycemic Index of Tuber Foods

Resistant Starch: Pembentukan, Metabolisme dan Aspek Gizinya.

Resistant Starch: Pembentukan, Metabolisme dan Aspek Gizinya.

Indeks Glikemik Umbi-umbian

Sumber: Hasil penelitian, 2017 